\title{
7. 空気圧駆動小型拍動流血液ポンプ
}

\author{
渋谷邦弘* 間島賢治* 手塚 均* \\ 土屋喜一* 島津秀昭** 山越憲一** \\ 戸川達男**
}

はじめに：体外循環および補助循環における 血液ポンプは, 古くから数多くの型式のものが 研究・開発されてきている1)。これらを駆動方 式から分類すると, 大きくモータ駆動型式と流 体駆動型式に分類される. 前者は構造上装置が 大型となり，循環回路を大掛りなものとしてい るが, 後者, 特に空気圧駆動型式では小型・軽 量とすることが可能で, 回路のコンパクト化も 期待できる。，一方，近年における長時間体外灌 流の必要性から，末梢循環に対する種々の生理 学的問題点も指摘され ${ }^{2)}$ ，この観点から拍動型 血液ポンプが開発されているが，その多くは機 構的制約から 1 回拍出量の調節が容易でない。 そこで今回著者らは以上の観点から, 装置が小 型で，1回拍出量の調節が容易であり，血液回 路を disposable 化した空気圧駆動型拍動流血 液ポンプを考案・試作した。

装置の原理と構造：図 1 （a）は装置の駆動 原理図である。主駆動部は，装置内空気室に供 給される圧縮空気と復元用スプリングにより， ピストンを上下動させ, 血液 chamber を圧迫 して（駆出率；80～90\%）血液を駆出する方式 である，流人，流出弁は，圧縮空気により小型 シリンダ (BFSAS-12.5-11 碀藤倉ゴム工業) を作動させ，血液回路を外部から压閉する方式 を採用して，血液回路の disposable 化を容易に した. 図 1 （b）は血液 chamber の模式図を 示したものである。この chamber は真空成形 した塩化ビニールシート（グラフトマー, 厚さ

* 早稲田大学理工学部

** 東京医科歯科大学医用器材研究所
$0.3 \mathrm{~mm}$ ，株日本ゼオン） 2 枚を溶着加工した ものを使用している，中間部は 4 本の梏円断面 形チューブ状に成形し，それぞれの容量は，1 回拍出量が $5 ， 10 ， 15 ， 20 \mathrm{~m} \ell$ となるように加 エしてある。これにより拍出量の調節は，各于 ューブの流入側をクランプすることにより， 5
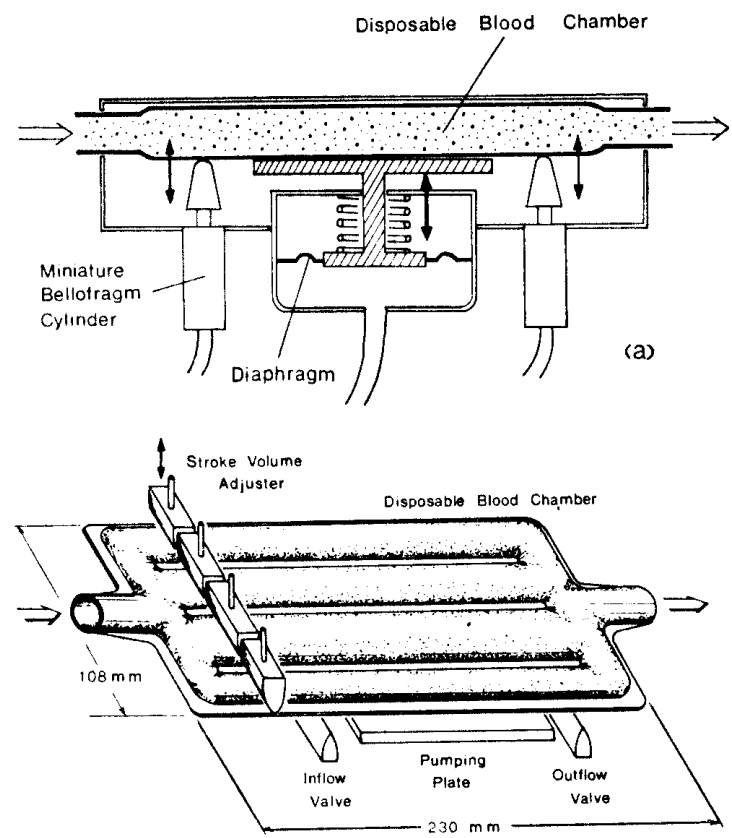

(b)

図1駆動原理図(a)および血液chamber模式図(b)

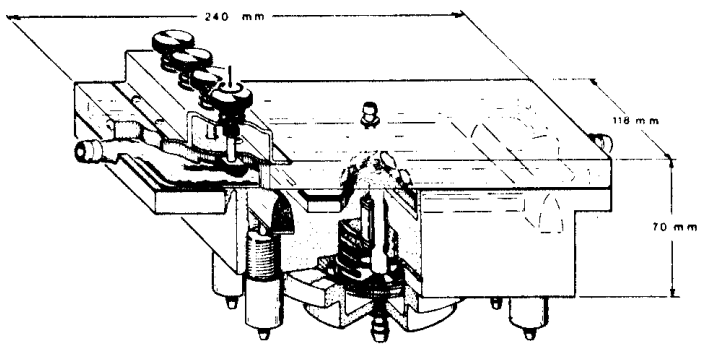

図 2 装置の構造模式図 
〜 $50 \mathrm{~m} \ell （ 5 \mathrm{~m} \ell$ ぎみ）の範囲で容易に調節可 能である。図 2 は試作した装置の構造模式図を 示したもので, 外形寸法 $240 \times 118 \times 70 \mathrm{~mm}$ の小 型なものである。1 回拍出量の調節は, 図中, 左上方のッマミによりワンタッチ操作で行え る。装置は本体と上蓋とに分解されるが，血液 chamber はその中間部偪設置され，装脱着を容 易に行えるようにした。上蓋はアクリル製で， 血液の駆出状況を観察できるようになってい る。また血液 chamber 装置部は密閉されてお り, その部分を院圧に保つことが可能で, chamber 内人の血液流入をすみやかに行わせると 同時に, 過度の吸引陰压による溶血を防止でき るようにエ夫した。この部分の陰圧を調節する

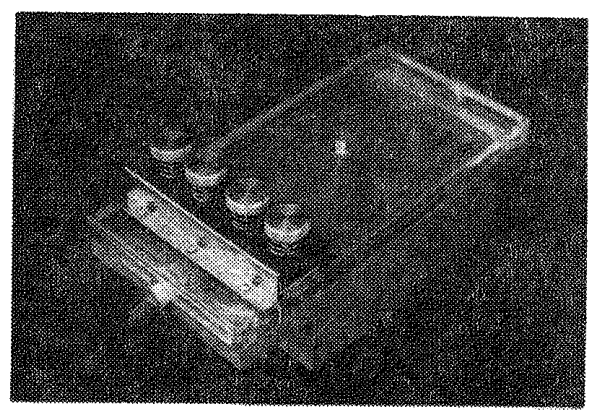

仕程と駆㖶条件

\begin{tabular}{|c|c|c|}
\hline 项 & 㩰 & 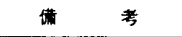 \\
\hline 1 回拍出量 & $5 \sim 50 \mathrm{~m} \ell$ & 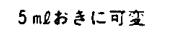 \\
\hline 拍 功 数 & $40 \sim 200 \mathrm{bpm}$ & 樌啭 $60 \sim 100 \mathrm{bpm}$ \\
\hline 匟 出 時 間 & $30-3000 \mathrm{~ms}$ & 椎隼 S/D比 \\
\hline 流入時 間 & $30 \sim 3000 \mathrm{~ms}$ & $1 / 0.5 \sim 1 / 5$ \\
\hline 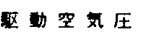 & $0 \sim 3 \mathrm{~kg} / \mathrm{cm}^{2}$ & 筧望 $1-1.5 \mathrm{~kg} \mathrm{~cm}^{2}$ \\
\hline 弁取的圧 & $0 \sim 5 \mathrm{~kg} / \mathrm{cm}^{2}$ & 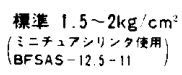 \\
\hline 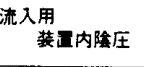 & $0 \sim-100 \mathrm{mmHg}$ & 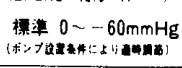 \\
\hline
\end{tabular}

図 3 装置外観とその仕様

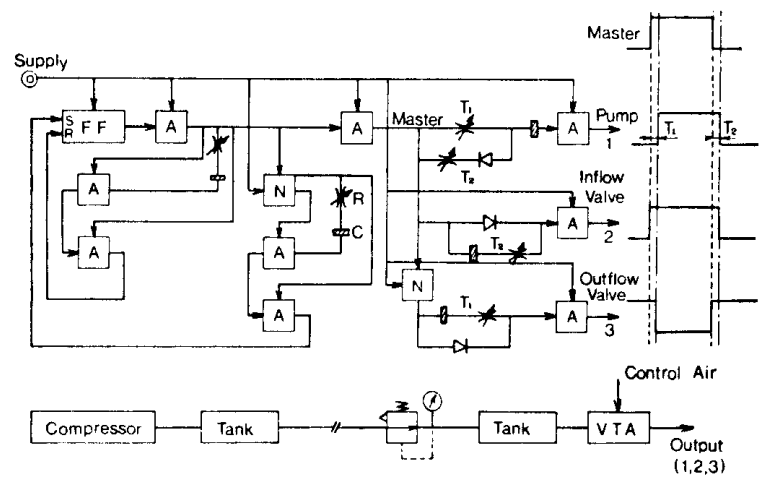

図 4 空気圧制御回路

FF : flip-flop, $A:$ and, $N:$ not, $R:$ 絞り, C : 容量
ことにより，ポンプの設置高さが任意に選心゙る ことも利点である。図 3 は, 試作したポンプの 外観および仕様をまとめたものである。

ボンプ制御回路：図 4 は，本装置の空気圧制 御回路を示したものである。ポンプ主駆動およ び流大，流出弁用空気圧制御信号は，同図に示 す non-bleed 型流体素子で発生させ，ここで得 た空気圧信号で空動弁(VTA-315 粕焼結金属) を作動させてポンプ動作を行ら。まず基準信号 の立上りに同期して，流入弁を閉鎖し，遅延時 間 $\mathrm{T}_{1}(0 \sim 200 \mathrm{~ms}$ 範囲で調節可能) 後に流出 弁を開放すると同時に血液駆出を行う。次に基 準信号の立下りに同期して流出弁の閉 鎖を行 い, 遅延時間 $\mathrm{T}_{2}(0 \sim 200 \mathrm{~ms}$ 範囲で調節可能 $)$ 後に流入弁を開放して血液流入を行うようにし た. 本制御回路は, 拍動数 $40 \sim 200 \mathrm{bpm}$, 標準 $\mathrm{S} / \mathrm{D}$ 比 1/0.5 1/5 の範囲で連続調節可能であ る。（図 3 参照）

特性試験とその結果：試作した装置のポンプ 特性を調べるため,ここでは流体として生理食 塩水を用いて in vitro試験を行った，実験用回 路はポンプ流入部の圧力を変化させる流入用夕 ンク, および流出部の压力を変化させる流出用 オーバーフロータンクから構成される。ポンプ
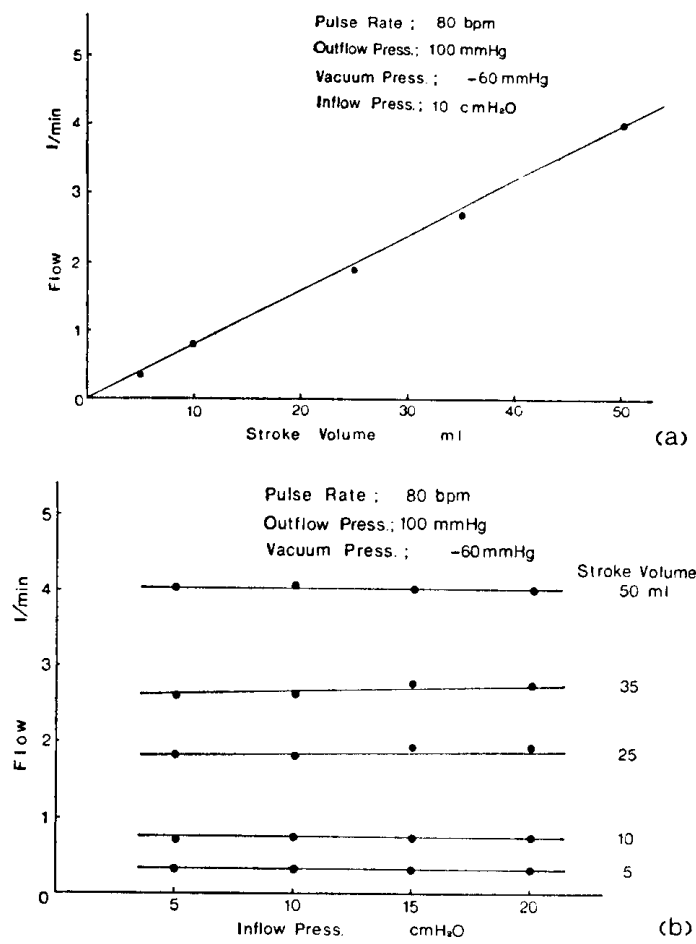

図 51 回拍出量に対する流量(a)および 流入圧力に対する流量(b) 

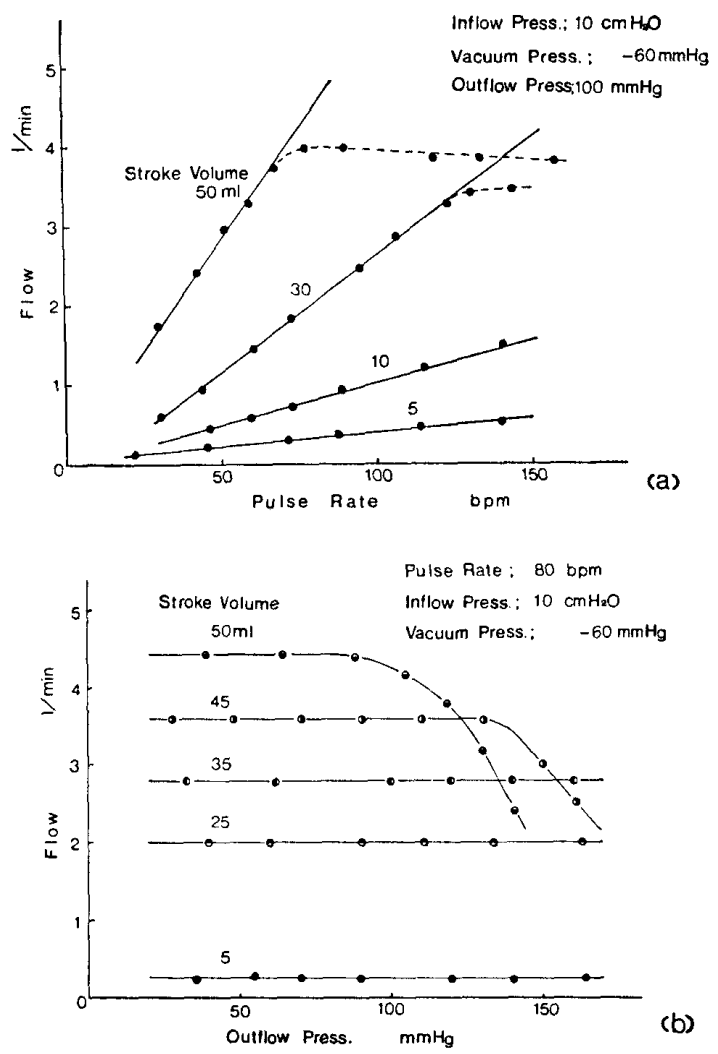

図 6 拍動数に対する流量(a)およひ 流出圧力に対する流量 (b)

駆出量は重量法および電磁流量計法により測定 した。な打供給駆動空気圧は，主駆動に対して は $1 \mathrm{~kg} / \mathrm{cm}^{2}$, 弁駆動に対しては $1.5 \mathrm{~kg} / \mathrm{cm}^{2}$ に 設定し，S/D 比は1/1.5とした. 図 5（a）は， 拍出量ツマミにより各チューブをクランプして 1 回拍出量を変化させ，血液 chamber内容積に 対する流量を求めたグラフである，図の直線は 理論值であるが実験值とよく一致しており，こ のような簡単な操作で拍出量調節を行えること がわかる. 図 5 (b) は流入部圧力を変化させ た時の流量を，1回拍出量をパラメータとして 求めたものである。これは chamber装着部の陰 圧を $-60 \mathrm{mmHg}$ とした場合の結果であるが， このように陰圧を適時用いることにより 1 回拍 出量と無関係に十分な流入を確保できる。また 流入部圧力，すなわち実際の体外循環における ポンプの設置高さに影響されないことが本図か ら理解される. 図6（a）は拍動数を変化させ た時の駆出流量を1回抬出量をパラメータとし て求めたものである. 本装置は 1 回拍出量の調 節が $5 \mathrm{~m} \ell$ おきであり,さらに駆出流量の微調 を行うには拍動数を変化させれば良く，グラフ に示されるよらに常用の拍動数（60～120bpm) では，拍動に比例した流量が得られる。図 6 （b）は，流出部圧力に対する駆出流 量を，1 回拍出量をパラメータとして求めたグラフであ る。同図から明らかなように，生理的動脈圧に 相当する流出部压負荷に対してはポンプの定流 量性が維持されている.

結語：今回試作した血液ポンプは前述のよう に, 装置全体が小型化され，かつ血液 chamber が disposableで，その装脱着も容易である。さ らに chamber 一の血液流入は流入玨に依存 せ ず，装着部陰压により十分確保される。またポ ンプ駆出流量は流出圧負荷によらずほぼ定流量 性を有することから，各容量のチューブ選択， および拍動数の適正な調節により駆出流量を容 易に設定・算出できる，以上のように本装置 は，体外循環用血液ポンプとして十分な特性を 有している. 今後, 長時間灌流実験による血栓 形成, 溶血の問題を検討すると共に, 血液 chamber の耐久性や形状の最適化扝よび emergency対策等についても検討してゆきたい，

最後に，血液chamber の製作に当りご協力い ただいた日本ゼオン侏辻葑氏に梁く感謝する。

\section{参考文献}

1) Galletti, P. M. : V11l. Theory of Blood Pumps. In : Heart-Lung Bypass : Principles and Technique of Extracorporeal Circulation

2)湯浅 浩：拍動流灌流に上る長時間体外循環につ いて, 日胸外会誌 20, 296 300, 1972

付 議

\section{泉工医科工業 若 井 秀 治}

1）塩化ビニールチャンバを弁用のバーで， 圧迫する場合に $400 \mathrm{mmHg}$ 前後の圧に耐えるよ らなバーの圧迫力を必要とします。

その場合にビニールチャンバの耐久性に問題 があると思いますが，この点どう扔考えでしょ うか。

\section{東女医大医工研 壁 井 信 之}

2) ポンプの 1 回拍出量を変化させるさい, チューブをクランプするため血液がチューブ内 に残留し凝血が生じると思われるが，その点を 
どのように考えているのか扔教え下さい.

\section{三重大胸部外科 草 川 実}

3 ）流出側抵抗として $150 \mathrm{mmHg}$ までを用い ておられるが，臨床応用する際には $300 \mathrm{mmHg}$ 前後になると思われるが，この時の人工心拍出 量の変化はどのようになると考えられるか。

回 答

\section{早大理工 渋 谷 邦 弘}

1) 弁用圧閉部の材質を硬質ポリウレタン （ADAPT-80P，粕日本ユニポリマー）とし て局部的な力が加わらないように工夫しており ます，血液チャンバ（材質；グラフトマー R 一5 (侏日本ゼオン)の機械的強度はポンプ使用に 十分でありますが，繰り返し圧閉に関する耐久
性については, 今後モデル実験ならびに長時間 灌流実験により検討を加えてゆこうと考えてお ります。

2 ) ejection fraction を90\%程度としている ため血液の残留は少なく，またへパリンの適用 により，現在行っている短時間（ $2 \sim 3$ 時間） の体外循環実験においては，そのような現象は 認められて打りません。

3 ）実験結果は駆動空気圧を $1 \mathrm{~kg} / \mathrm{cm}^{2}$ とし た際のものであり，この供給空気圧を大きくす ることにより十分な出力圧および拍出量を得る ことができ，後負荷効果の改善が期待できま す。な押，本実験での後負荷圧とは生体側動脈 圧に相当するもので, ポンプカニューラ出口端 の圧力です。 